\title{
Changes in Land Use Systems Alter the Phosphorus Nutrition and Associated Soil Fertility Status
}

\author{
Didar Ahmad', Farhan Hafeez ${ }^{1 *}$, Hesham F Alharby ${ }^{2}$, Atif A. Bamagoos ${ }^{2}$, \\ Khalid Rehman Hakeem², Mona H. Soliman ${ }^{3}$, Sahab Masood Pasha ${ }^{1}$, \\ Imran Khan ${ }^{4}$, Bilal AZ Amin ${ }^{1}$, Faridullah ${ }^{1 * *}$ \\ ${ }^{1}$ Department of Environmental Sciences, COMSATS University Islamabad, Abbottabad Campus, \\ Tobe Camp University Road Abbottabad 22060 Pakistan \\ ${ }^{2}$ Department of Biological Sciences, Faculty of Science, King Abdulaziz University, Jeddah-21589, Saudi Arabia \\ ${ }^{3}$ Botany and Microbiology Department, Faculty of Science, Cairo University, Giza 12613, Egypt \\ ${ }^{4}$ Department of Management Sciences, COMSATS University Islamabad, Abbottabad Campus, \\ Tobe Camp University Road Abbottabad 22060 Pakistan
}

Received: 29 October 2019

Accepted: 28 December 2019

\begin{abstract}
Improved plant nutrition to get high productivity is under severe influence of human activities drastically impacting the soil-plant ecosystem. In the scenario of increased global socio-economic demand for food, the changes in land use systems to gain higher agricultural productivity are disrupting the soil properties as well as the associated soil services. This work investigated the impact of different land use systems on phosphorus (P) and associated soil nutrients including $\mathrm{K}, \mathrm{Ca}$ and $\mathrm{Mg}$ across six different land use systems in Abbottabad, Pakistan. Phosphorous fractions were determined by the modified sequential extraction procedures and the concentration of nutrients was measured by double acid digestion. Results revealed the significant variations across different land use systems for $\mathrm{P}$ where different $\mathrm{P}$ fractions were found considerably varying in order of $\mathrm{HCL}>\mathrm{NaOH}>\mathrm{NaHCO}_{3}>\mathrm{H}_{2} \mathrm{O}$ extractable phosphorus. Interestingly, nutrients were found to be varying from thick forest to cultivated lands. Results demonstrate that the shift from the thick forests to thin forests or arable lands may increase the P losses and ultimately disturb the associated soil-plant nutrient status thus should remain intact to promote the plant productivity in a sustainable way.
\end{abstract}

Keywords: land uses, nutrient losses, plant nutrition, phosphorus, soil environment

\footnotetext{
*e-mail: faridullah@cuiatd.edu.pk
} **e-mail: drfarhan@cuiatd.edu.pk 


\section{Introduction}

Land use change under influence of the changes in productivity demand and variable climate is ultimately affecting the soil functioning and its properties [1-2]. The different types of land use systems are also important for the efficient and balanced ecosystem productivity [3], conversely the unplanned and unmanaged development in the cities degrades land systems but also the overall environment [4]. Such changes in lands uses are also resulting due to the changes in the cities and constructions of large-scale buildings and infrastructure [5]. The lands mainly used for agriculture, and the extensive agricultural activities ultimately disturb the ecology and sustainability of the natural environment [6-7]. The changes in the land-use change due to the global socio-economic demand for the rapid increase of population is problem for globe [8]. Due to intensive agriculture focusing on highyielding crop varieties, heavy fertilization, irrigation through pumping the underground water, and the high doses of pesticides soil degradation is increasing enormously. Besides this, the deforestation to increase the agricultural farms is also contributing towards soil degradation, which in turn has resulted in a strong decrease in tropical forests [9]. Such demand increased agricultural productivity is ultimately causing the land use change as well as deforestation in tropics [10].

These terrestrial ecosystems facing a severe change in land use system are not only important for plant production but are crucial for climate regulation, water quality, biodiversity, and nutrient cycling [11]. Soil is affected by human activities and mismanagement of land uses as well as under impact of climate change induced alterations is consequently causing land degradation and desertification [12]. This asks for sustainable soil management to continue the soil to provide the associated services [13]. Management of the land use systems is necessary to maintain the life processes on earth [14]. However, this has adversely been shifted due to both natural and man-made activities for example for increased urban population and constructed large cities and recreational places. For sustainable life processes and betterment of the environment, there is a need of planning for the soil management mainly in big cities through urban agro-forestry [15].

There are many studies carried out on, phosphorus as a limiting factor for the plant growth [16]. Phosphorus $(\mathrm{P})$ is one of the limiting factors for the productivity in general and in tropics in specific [17-18]. The abovementioned land use change not only alters the soil physicochemical properties but these human activities may also result in the transformations in terrestrial ecosystems through impacting the essential nutrients like C, N and P in soil [19]. For example, the soil P may also indirectly affect the nitrogen inputs as well as atmospheric nitrogen fixation [20]. Soil is the major source of $\mathrm{P}$ for plant growth in terrestrial ecosystems and this $\mathrm{P}$ concentration in soil is significantly higher under forests soils as compared to lands exposed to deforestation and/or agricultural lands [21]. Despite of this large amounts of $\mathrm{P}$ in soils (typically between 50 and $1500 \mathrm{mg} \mathrm{kg}^{-1}$ ), soil available $\mathrm{P}$ is often reported as short [8] where only soluble inorganic $\mathrm{P}$ in soil is directly available to plants [22]. This soil soluble inorganic $\mathrm{P}$ represents a small but variable fraction of the soil total P. For example, soluble inorganic P extracted by resin ranges from $<0.1-222.0$ (mean 17.2) $\mathrm{mg} \mathrm{kg}^{-1}$ [23]. Further, the soil $\mathrm{P}$ concentration vary according to the soil type that can further be affected by various the physiochemical properties such as soil $\mathrm{pH}$, organic matter content and texture, and biological activities such as biological immobilization and the secretions of lowmolecular organic acids and phosphatase enzymes [22]. Coarse soil particles feature low $\mathrm{P}$ sorption capacity relative to fine soil particles; therefore, $\mathrm{P}$ solubility may vary with soil texture also affected by organic matter microbial activities (immobilization) [24-25]. About $3.2 \%$ annually increase of $\mathrm{P}$ fertilizer increased by from 2002 to 2010 for agriculture. The results of the study determine that about half of the total input remains and accumulated in the agricultural systems, the rest of $\mathrm{P}$ input lost through water bodies in the form of complex flows [26].

An improved understanding about the variability in soil $\mathrm{P}$ solubility and associated drivers is critical to comprehend the different management strategies to ultimately cope with $\mathrm{P}$ limitation important for primary productivity in terrestrial ecosystems under severe influence of changes in land use system [27] For example, any shift in land use and fertilization may impact the soil nutrition and soil $\mathrm{P}$ in particular with marked increase in its inorganic form or a depletion of organic form especially in arable soil ecosystem [28].

Tropical regions are widely expected to play a growing role in global agricultural production [29] and croplands in these regions are often characterized by highly weathered soils having low phosphorus (P) stocks and high capacity for $\mathrm{P}$ sorption (i.e., $\mathrm{P}$ fixation) [30]. These soils are rich in iron and aluminum oxides that fix $\mathrm{P}$ added in fertilizers before it can be accessed by crops [31]. Human activities increased the phosphorus in terrestrial and freshwater ecosystem to at least $75 \%$. A large portion of the phosphorus release is in agricultural lands and the rate is increasing in the developing countries [32]. A large area of natural wetlands $(3,800,000 \mathrm{ha})$ and forest lands $(1,200,000 \mathrm{ha})$ are already converted into agricultural lands. However, how much the effects of this change impact on the chemical forms of phosphorus in soil profile still demands investigations [33].

The current study aims to investigate how the changes in the land use systems impact on phosphorus and associated soil nutrient status. The focus of study is Abbottabad, which have different type of land use systems; e.g. thick forests thin forests, pastures, and agricultural lands. Our objective is to understand how 
the changes in land use systems have affected the soil nutrient as well as $\mathrm{P}$ status and other nutrients like $\mathrm{Ca}, \mathrm{Mg}$ and $\mathrm{K}$ concentration in the different land use systems.

\section{Materials and Methods}

\section{Study Area and Soil Sampling}

The study area comprising of six different land systems (Thick Forest (TKF), Thin Forest (TNF), Pasture Land (PSL), Fallow Land (FWL), Wheat Cultivated Land (WCL) and Maize Cultivated Land $(\mathrm{MCL}))$ is located at District Abbottabad $\left(72-74^{\circ} \mathrm{E}\right.$ and $34-36^{\circ} \mathrm{N}$ ) The samples were collected from mentioned different land use systems at two depths (top soil $0-20 \mathrm{~cm}$ and sub soil $20-100 \mathrm{~cm}$ ) followed composite soil sampling technique with three replicates each time $(\mathrm{n}=3)$. These samples were sieved $(<0.5 \mathrm{~mm}$ mesh size $)$ and brought to laboratory for further analyses.

\section{Physicochemical Properties Analyses}

The physicochemical properties were measured through standard laboratory procedures. Soil particle size distribution was determined by Hydrometer Method as [34] and textural class according to USDA system. $50 \mathrm{~g}$ of air-parched soil was taken in a beaker. Sodium hexametaphosphate solution $(50 \mathrm{~mL}, 2 \%)$ was added as a supplementary in the beaker as a dispersing agent. To ease the reaction, distilled water $(150 \mathrm{~mL})$ was also added to the suspension. The suspension was then agitated with a mechanical shaker for 10 minutes and shifted to $1000 \mathrm{~mL}$ graduated cylinder. The suspension was shaken briskly with a metal spoon. The first reading was noted after 40 seconds of trembling and final reading was taken after 2 hours on Bouyoucos Hydrometer. The temperature was also measured at each reading. The calculations were monitored for the percentage of sand, silt, and clay. Soil textural class was determined with international soil classification system (ISSS).

The soil moisture content was calculated using the method of Black [35]. It is expressed by a ratio of the dry weight of water to the dry weight of soil in a sample. To determine this ratio for a particular soil sample, the water mass was determined by drying the soil to constant weight and measuring the soil sample mass before and after drying. The water mass is the difference between dry weight to the wet weight of the soil samples. The soil samples were dried to constant weight in an oven at $105^{\circ} \mathrm{C}$ for 24 hours. The calculation for each sample was done by using the formula:
Where: mass of water is the difference between weight of the sample before drying and weight of the sample after drying. Likewise, mass of soil is the weight of oven dried sample.

The carbon was detected in total organic form. For the purpose, dry combustion method was used. The procedure proceeded as, $25 \mathrm{~g}$ of soil sample in china dishes and noted their weights accordingly. These samples were then combusted at $550^{\circ} \mathrm{C}$ for 2 hours. Then it was weighted again and noted their readings. Then volatile solids (VS) were calculated by using the formula as:

$$
\text { VS }(\%)=(\text { wet soil }- \text { dry soil }) / \text { wet soil }) * 100
$$

The total organic carbon in the soil samples were calculated by:

$$
\mathrm{TOC}=\mathrm{VS} / 1.8
$$

The soil chemical properties like $\mathrm{pH}$ and electrical conductivity (EC) were determined using saturated paste and extract of soil, respectively, [36] using soil/ water ratio (w/v) of 1:5 [37]. The $\mathrm{pH}$ of amended soils and compost was determined using a $10 \mathrm{~g}$ sample mixed with $100 \mathrm{~mL}$ of deionized water, which was stirred and left for $30 \mathrm{~min}$ at room temperature $\left(22^{\circ} \mathrm{C}\right)$. The suspension was tested for $\mathrm{pH}$ using a $\mathrm{pH}$ meter, while its electrical conductivity was found by using a digital conductivity meter.

\section{Phosphorus Fractionations}

Phosphorous fractions were determined by the modified sequential extraction procedure of [38], as described by [39]. This procedure was proceeded as, a soil of weight $5 \mathrm{~g}$ was placed in a $50 \mathrm{~mL}$ centrifuge tube. After this, it was fractionated into labile inorganic readily plant- available $\mathrm{P}, \mathrm{Al}-$ and $\mathrm{Ca}-$ associated $\mathrm{P}$ by sequential extraction. A deionized water of $30 \mathrm{~mL}$ was added and then $0.5 \mathrm{M} \mathrm{NaHCO}_{3}$ and 8.5 of $\mathrm{pH}$ was adjusted. After it about $0.1 \mathrm{M} \mathrm{NaOH}$, and then $1 \mathrm{M} \mathrm{HCl}$, respectively was added to samples. These extracted samples then were shaken continuously for about $16 \mathrm{~h}$ in shaker at room temperature and centrifuged at $10000 \mathrm{rpm}$ for $10 \mathrm{~min}$. the supernatant extracted to different bottles and filtered through $0.2 \mu \mathrm{m}$ size filter paper.

Ammonium acetate soluble cations $(\mathrm{Ca}, \mathrm{Mg}$ and $\mathrm{K})$ were extracted with $1 \mathrm{M} \mathrm{NH} \mathrm{NH}_{4} \mathrm{OAc}$, adjusted to $\mathrm{pH}$ 7.0 [40]. The soil samples weighing $3 \mathrm{~g}$ were kept in $100 \mathrm{~mL}$ centrifuge tubes. After this $25 \mathrm{~mL} \mathrm{NH}_{4} \mathrm{OAc}$ (1:5) solution was added and it will be shaken for $2 \mathrm{~h}$ for proper mixing. This sample then kept in centrifuge machine for $10 \mathrm{~min}$ at $2400 \mathrm{rpm}$. The supernatant was filtered into a $100 \mathrm{~mL}$ volumetric flask. The extracts were used for determination by atomic absorption spectrophotometer. 
Table 1. Physico-chemical properties of the soils of different land use systems.

\begin{tabular}{|c|c|c|c|c|c|c|c|c|}
\hline \multirow{2}{*}{$\begin{array}{l}\text { Soil } \\
\text { Horizon }\end{array}$} & \multirow{2}{*}{$\begin{array}{l}\text { Land } \\
\text { use }\end{array}$} & \multicolumn{3}{|c|}{$\begin{array}{l}\text { Particle Size } \\
\text { Distribution }\end{array}$} & \multirow{2}{*}{$\begin{array}{c}\text { Moisture } \\
\%\end{array}$} & \multirow{2}{*}{$\frac{\mathrm{OM}}{\mathrm{g} \mathrm{Kg}^{-1}}$} & \multirow{2}{*}{$\mathrm{pH}$} & \multirow{2}{*}{$\begin{array}{c}\mathrm{EC} \\
\mathrm{dS} / \mathrm{m}\end{array}$} \\
\hline & & Silt \% & Clay \% & Sand \% & & & & \\
\hline \multirow{6}{*}{$\begin{array}{l}\text { Top } \\
\text { Soil }\end{array}$} & TKF & $49.3 \pm 1.2$ & $29.9 \pm 1.5$ & $20.8 \pm 0.3$ & $19.5 \pm 2.5$ & $93.3 \pm 4.7$ & $6.75 \pm 0.0$ & $1.36 \pm 0.0$ \\
\hline & THF & $47.5 \pm 1$ & $28 \pm 2.4$ & $24.5 \pm 3.4$ & $16 \pm 3$ & $83.9 \pm 0.4$ & $6.47 \pm 0.2$ & $1.53 \pm 0.4$ \\
\hline & FL & $50 \pm 1.5$ & $27.2 \pm 0.8$ & $22.9 \pm 2.3$ & $14.5 \pm 1.5$ & $75.9 \pm 8.9$ & $7.4 \pm 0.1$ & $1.46 \pm 0.3$ \\
\hline & PL & $47.7 \pm 1.2$ & $25 \pm 1.5$ & $27.3 \pm 0.3$ & $14.5 \pm 2.5$ & $70 \pm 4.3$ & $6.85 \pm 0.3$ & $1.33 \pm 0.1$ \\
\hline & WCL & $50.1 \pm 1.4$ & $26.5 \pm 1.1$ & $23.6 \pm 0.3$ & $12.5 \pm 3.5$ & $66.1 \pm 1.4$ & $7.75 \pm 0.2$ & $1.43 \pm 0.2$ \\
\hline & MCL & $51.1 \pm 1.4$ & $27.5 \pm 1.1$ & $21.5 \pm 0.3$ & $16 \pm 3$ & $65.5 \pm 2$ & $7.3 \pm 0.1$ & $1.7 \pm 0.1$ \\
\hline \multirow{6}{*}{$\begin{array}{l}\text { Sub } \\
\text { Soil }\end{array}$} & TKF & $52.3 \pm 1$ & $27.1 \pm 1.5$ & $20.7 \pm 0.5$ & $13.5 \pm 1.5$ & $53 \pm 1.3$ & $6.6 \pm 0.1$ & $1.41 \pm 0.0$ \\
\hline & THF & $50 \pm 1.4$ & $27.9 \pm 1.5$ & $22.2 \pm 2.9$ & $11 \pm 3$ & $36.6 \pm 0.8$ & $6.55 \pm 0.2$ & $1.73 \pm 0.1$ \\
\hline & FL & $52 \pm 1.5$ & $26.8 \pm 2.2$ & $21.3 \pm 3.7$ & $11 \pm 2$ & $28.1 \pm 0.6$ & $6.6 \pm 0.1$ & $1.41 \pm 0.1$ \\
\hline & PL & $53.3 \pm 0.8$ & $25.9 \pm 1.4$ & $20.8 \pm 0.6$ & $15 \pm 3$ & $30.6 \pm 1.6$ & $7.65 \pm 0.2$ & $1.44 \pm 0.1$ \\
\hline & WCL & $54.3 \pm 1.1$ & $27.4 \pm 2.1$ & $18.4 \pm 3.1$ & $13.5 \pm 2.5$ & $27.1 \pm 0.3$ & $7.85 \pm 0.2$ & $1.52 \pm 0.1$ \\
\hline & MCL & $55.5 \pm 2.1$ & $23.5 \pm 2.1$ & $21.1 \pm 0.0$ & $14 \pm 1$ & $24 \pm 0.3$ & $7.9 \pm 0.1$ & $1.6 \pm 0.0$ \\
\hline
\end{tabular}

For water-soluble extracts, $3 \mathrm{~g}$ soil sample of weight was placed in a $100 \mathrm{~mL}$ tube. Then a volume of $50 \mathrm{~mL}$ deionized water was added and kept it in shaker for $2 \mathrm{~h}$. After centrifuge at $2400 \mathrm{rpm}$ for $10 \mathrm{~min}$, the supernatants were separated from the soil the Supernatants were filtered into a $100 \mathrm{~mL}$ volumetric flask. The extract was used for determination for watersoluble cations concentration by atomic absorption spectrophotometer.

\section{Nutrients Analysis}

The acid digestion is a method for the determination of nutrients in total form. As total form of $\mathrm{Ca}, \mathrm{Mg}$ and $\mathrm{K}$ in the samples were determined double acid digestion as, by perchloric acid $\left(\mathrm{HClO}_{4}\right)$ and nitric acid $\left(\mathrm{HNO}_{3}\right)$ in a conical beaker on a hot plate [41]. For the purpose a soil sample of weight $3 \mathrm{~g}$ was digested with $5 \mathrm{ml}$ highly concentrated $\mathrm{HClO}_{4}$. After adding the acid, the samples were heated on hot plate for 1 hour. When the perchloric acid dry then $1 \mathrm{~mL}$ of $20 \%$ nitric acid will be added and heated again on the hot water bath for $1 \mathrm{~h}$. These samples were kept in open air for cooling. After proper cooling $50 \mathrm{~mL}$ deionized water was added and wash properly and were passed through $0.22-\mu \mathrm{m}$ filter. These filtrates were centrifuged at $1000 \mathrm{rpm}$ for $15 \mathrm{~min}$ and the supernatant were collected in separate bottles. The clear supernatant in separate bottles were run in atomic absorption spectrophotometer against the standards for total forms nutrient's concentration in the soil.

\section{Statistical Analysis}

The data collected during the studies were statistically analyzed using the Stat View software. A probability level of heavy metals $<0.05$ was considered significant, and means were separated by Fisher's least significant difference (LSD) test [42].

\section{Results}

\section{Physico Chemical Properties of the Soil}

The physicochemical properties of the different land use systems were shown in the Table 1. The particle size distribution in the form of sand, silt and clay shows that the soil of the region was loamy with the silt concentration ranging from $47.7 \%-55.45 \%$ and clay percent varies from $23.45-25.95 \%$. However, the sand percent was significantly low that ranged from $18.35-27.3 \%$ (Table 1). The moisture percent was significantly higher in the thick forests $(19.5 \%)$ soils and it was shown minimum in the WCL. The subsoil moisture percent showed a variable trend with maximum value for MCL and minimum for thin forests soils (THF) and fallow land (FL). Organic matter was recorded significantly higher in thick forests (TKF) (93.3 $\mathrm{g} \mathrm{Kg}^{-1}$ ) followed by THF (83.9 $\mathrm{g} \mathrm{Kg}^{-1}$ ) (Table 1). We observed that the organic matter content in cultivated soil was significantly lower (WCL and MCL) for topsoil whereas the sub soil organic matter was significantly lower. Overall the $\mathrm{pH}$ ranged from 6.47-7.75 and 6.6-7.9 in topsoil and subsoil respectively.

\section{Phosphorus Fractions in the Six Land Use Systems}

The phosphorus concentration in the different land use systems ranged from 1.28-4.8 $\mathrm{mg} \mathrm{Kg}^{-1}$ as shown in 


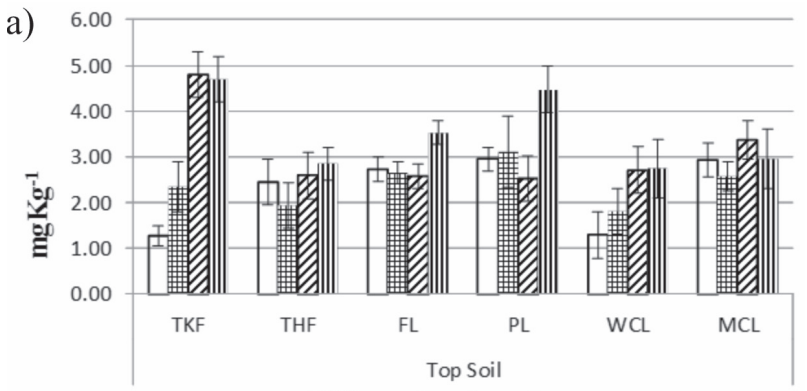

Different Land use Systems

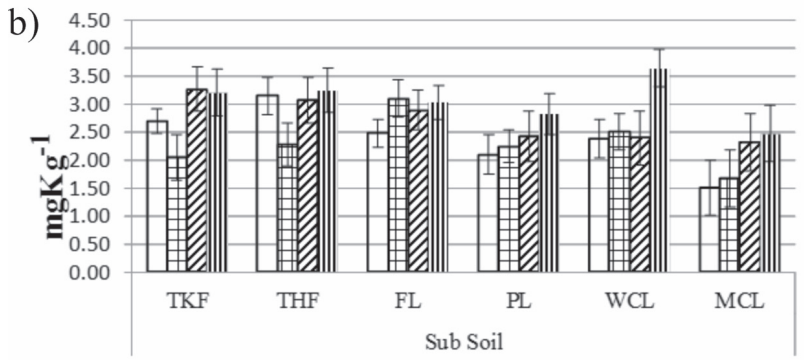

Different L and use Systems

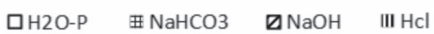

Fig. 1. P fractions in the different land use systems.

Fig. 1. The results revealed that phosphorus fractions were found significantly different across the different land use systems. The phosphorus concentration was maximum in $\mathrm{HCl}$ extract form while it was minimum

a)

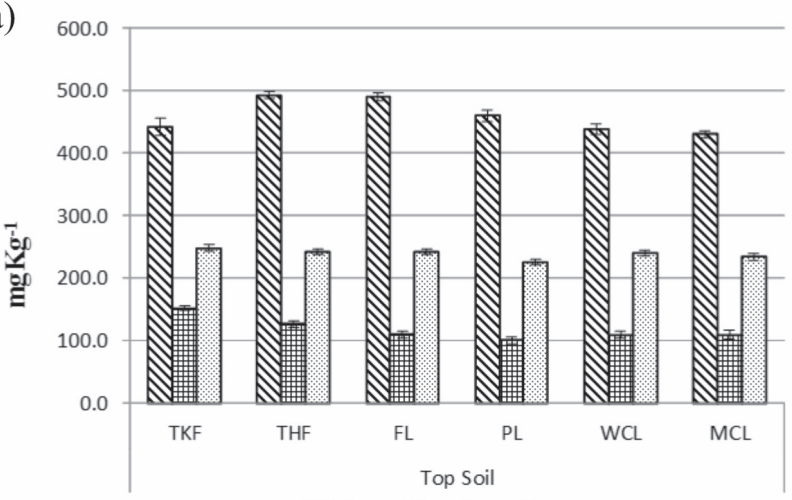

b)

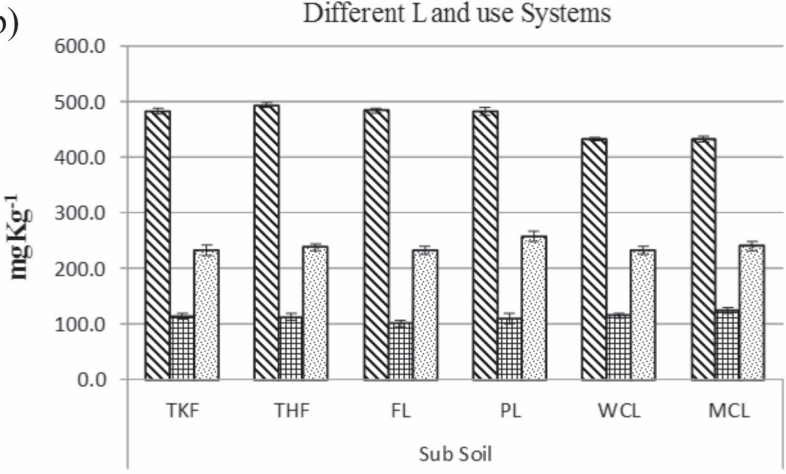

Different Land use Systems

QTotal-K 田H2O-K ФEXT-K

Fig. 2. K concentration in soil of different land use systems. in water-soluble form. We observed that $\mathrm{P}$ concentration was severely impacted for the subsoil samples. However, Thick forests (TKF) land use system showed similar type of trend both for subsoil and topsoil. The phosphorus concentration varied as $\mathrm{HCl}>\mathrm{NaOH}>$ $\mathrm{NaHCO}_{3}>\mathrm{H}_{2} \mathrm{O}$. The acid soluble $\mathrm{P}$ fraction was always higher whereas the water-soluble phosphorus was lowest in the both soil horizons (Fig. 1).

\section{Nutrients Concentrations in the Different Land Use Systems}

To assess the soil nutrient status further we quantified important macronutrients including Potassium, Calcium and Magnesium. The results showed that soil potassium concentration ranged from 110.7-493.2 $\mathrm{mgKg}^{-1}$ in the topsoil where THF and FL soils showed a higher potassium concentration as compared to $\mathrm{s}$ FL, PL and other cultivated lands both for top or sub soil. In subsoil samples, potassium concentration ranged from 100.9-493.3 $\mathrm{mgKg}^{-1}$. We found that the total potassium concentration was significantly higher in both soil horizons followed by the extractable form, but it was significantly lower in the water-soluble form (Fig. 3).

In the topsoil the total calcium concentration ranged from 44.8 to $512.3 \mathrm{mgKg}^{-1}$, followed by extractable calcium (226.1 to $288.8 \mathrm{mgKg}^{-1}$ ) and water-soluble calcium was varied as $93.9-135.5 \mathrm{mgKg}^{-1}$. The overall concentration of the calcium in three forms were varied as, total $>$ EXT $>$ WS. The subsoil showed the similar
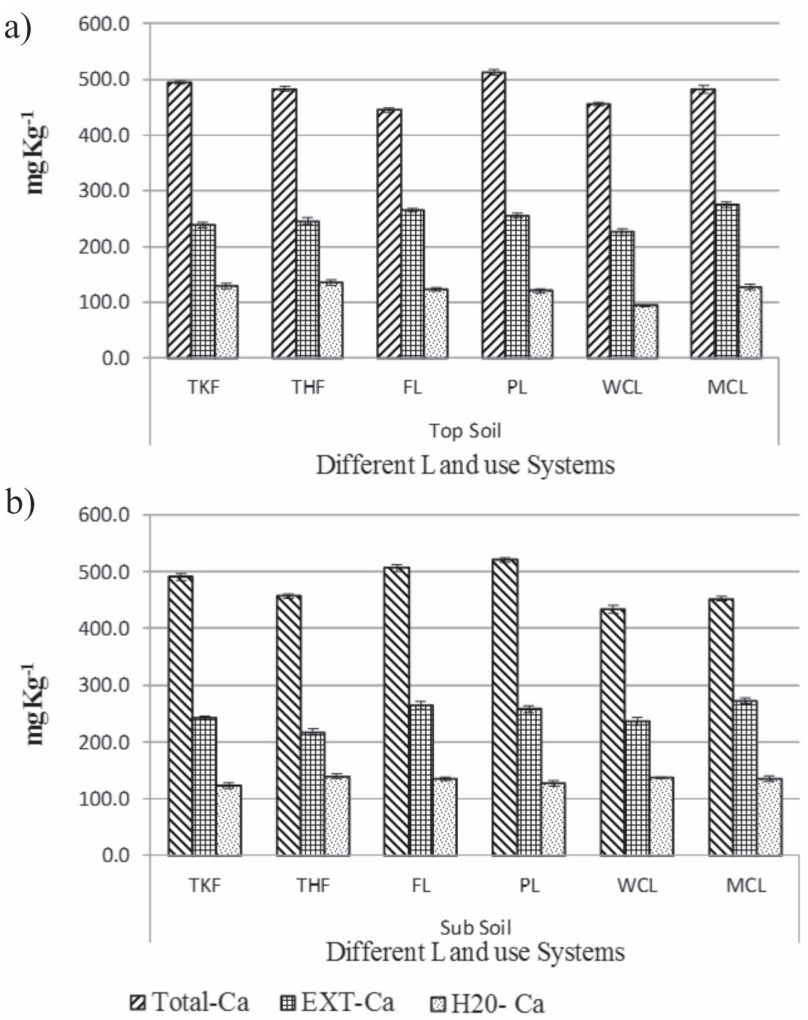

Fig. 3. Ca concentration in the different land use systems. 

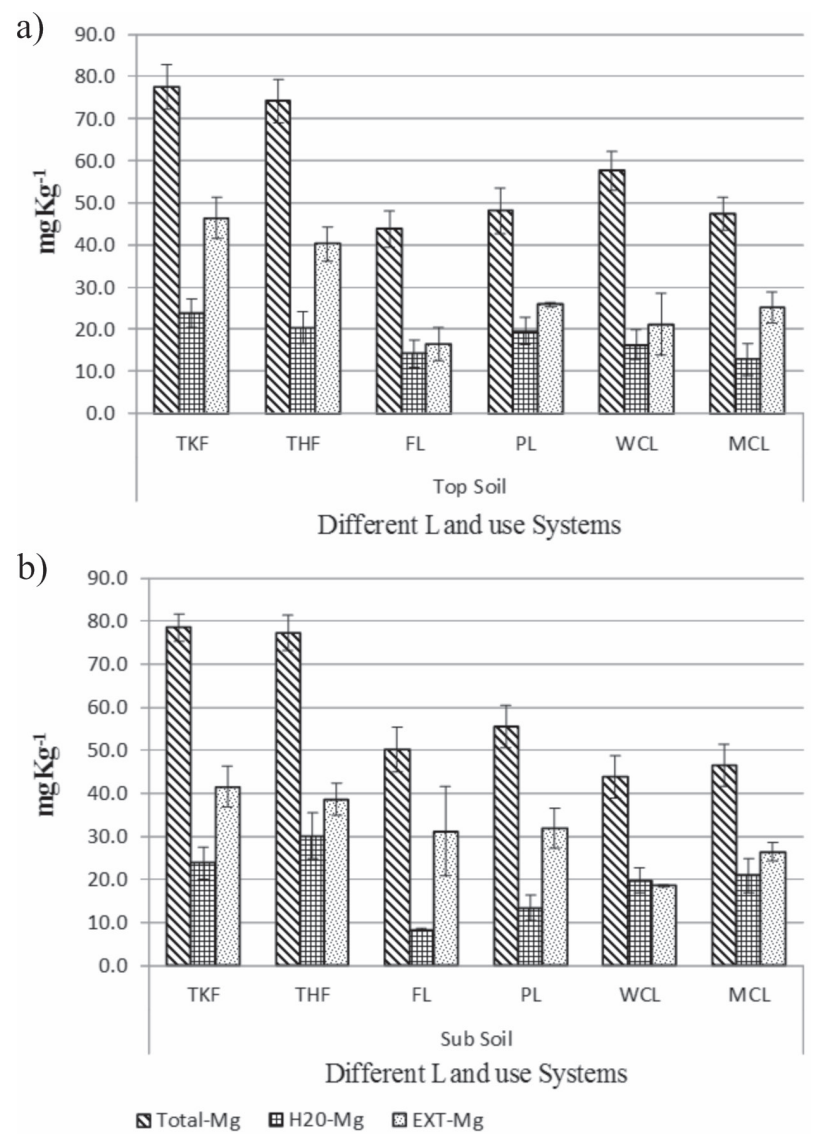

Fig. 4. Mg concentration in soil of different land use systems.

type of variation. The total calcium varied from 434.6-520.8 $\mathrm{mgKg}^{-1}$ in the subsoil followed by extractable calcium which minimum as $217.3 \mathrm{mgKg}^{-1}$. If we compare the calcium concentration between the land use systems, the calcium was minimum in the pasture lands and showed minimum in the cultivated lands as in Fig. 3b).

In the same manner the topsoil $\mathrm{Mg}$ concentration in the different land use systems shown in the Fig. 4a). The results from the Figure revealed that the total $\mathrm{Mg}$ was higher in the TKF (77.6 $\left.\mathrm{mgKg}^{-1}\right)$ followed by the thin forest soils THF soils, which was $74.2 \mathrm{mgKg}^{-1}$. While the fallow lands showed significantly lower magnesium concentrations in the topsoil. The variation of $\mathrm{Mg}$ in Extractable form from 16.5-46.4 $\mathrm{mgKg}^{-1}$ in WCL and TKF respectively. If we compare three forms of magnesium the results were varied as Total $>$ EXT $>$ water-soluble forms. The subsoil showed the similar type of trend as in topsoil as shown in the Fig. 4b). The total magnesium was maximum in TKF followed by THF as in topsoil, while it was significantly minimum in the WCL $\left(43.8 \mathrm{mgKg}^{-1}\right)$. The extractable form showed the similar type of trend and water-soluble magnesium was maximum in the in THF and minimum in the fallow lands subsoil as in the Fig. 4b).

\section{Discussion}

Soil is an important resource, which provides many services but is recently under the severe influence of human activities [43] resulting in continuous degradation and pollution. The land use changes are one of the important factors causing increased soil degradation in different parts of globe. For example, these changes in land use systems have drastically affected the soil nutrient status disrupting the services provided by soil. The current study investigated the impact of different land use systems on phosphorus and associated soil nutrients including $\mathrm{K}, \mathrm{Ca}$ and $\mathrm{Mg}$.

The phosphorus fractions of six different land use systems showed that $\mathrm{P}$ forms changed significantly during the fractionation with the overall sequential extraction for reagents was found considerably varying in order of $\mathrm{HCL}>\mathrm{NaOH}>\mathrm{NaHCO}_{3}>\mathrm{H}_{2} \mathrm{O}$. The mean level for phosphorus obtained in water soluble was greater in thick forests that followed the trend as TKF $>$ THF $>$ FL $>$ PL $>$ WCL $>$ MCL with $\mathrm{P}$ levels showing higher values for the top soil as compared to subsoil. Interestingly, water-soluble $\mathrm{P}$ extraction increased to maximum in TKF and lowest in the WCL. By implementing the best management practices, we can reduce phosphorus inputs in the agricultural landscapes. For instance, the phosphorus inputs reduced to $22 \mathrm{~kg} / \mathrm{ha} /$ year in the agricultural lands [44]. The main levels for the release of $\mathrm{P}$ obtained in $\mathrm{NAHCO}_{3}$ was maximum in topsoil and varied as $\mathrm{WCL}>\mathrm{TKF}>\mathrm{FL}>\mathrm{MCL}>\mathrm{THF}>\mathrm{PL}$. According to Horst [45], the crop pattern and cultivation variation changes the phosphorus dynamics in the different lands. It occurs mainly due to the $P$ recycling mobilized by crop residues as well as colonization of $\mathrm{P}$ solubilizing microorganisms in rhizosphere of succeeding crops in a crop rotation system.

For $\mathrm{NaOH}$ extracted $\mathrm{P}$ varied in order of WCL $>\mathrm{TKF}>\mathrm{FL}>\mathrm{MCL}>\mathrm{THF}>\mathrm{PL}$ and the maximum concentration was observed in TKF while lowest in PL. The transformation of natural ecosystems into cultivated areas alters the distribution of $\mathrm{P}$ forms in the soils mainly in organic forms and generally such organic $\mathrm{P}$ declines in continuous cropping systems without phosphate fertilizers [46]. P extracted with $\mathrm{HCl}$ were as $\mathrm{TKF}>\mathrm{HF}>\mathrm{FL}>\mathrm{WCL}>\mathrm{MCL}>\mathrm{PL}$ where higher concentration was found for the TKF. $\mathrm{HCl}$ extractable inorganic $\mathrm{P}$ is the predominant form in all profiles, both as absolute values and as a percentage extracted $\mathrm{P}$ [47]. The total $\mathrm{P}$ concentration that showed the highest concentration for the TKF while lowest was for MCL. The various forms of $\mathrm{P}$ present to a large degree determine the fate and transport of $\mathrm{P}$ in soils [48]. As previously studied the impact of land use changes to grassland to short rotation plantation forests, showing an increase of inorganic $\mathrm{P}$ and decrease of organic $\mathrm{P}$ in the soils [49].

To assess the soil nutrient status across different land use systems, various nutrients were also extracted 
and their concentration was found to be varying as $\mathrm{Ca}>\mathrm{K}>\mathrm{Mg}$ in all three forms that is water soluble, extractable and total forms. The highest concentration of water-soluble $\mathrm{Ca}$ was observed in MCL while the lowest for WCL. Water-soluble $\mathrm{K}$ was highest in thick forest and minimum was noted in pastureland water soluble was highest in thick forest and minimum was observed fallow land. Extractable $\mathrm{K}$ was highest in wheat-cultivated land and minimum was observed in pastureland. Extractable $\mathrm{Mg}$ was highest in thick forest and minimum was observed in fallow land. We found that the total $\mathrm{Ca}$ was highest in MCL. It is evident that the net $\mathrm{Ca}$ mineralization in the forest floor and mineral soil is an important source of $\mathrm{Ca}$ for immediate plant uptake for all tree species [50].

We observed that overall soil phosphorus was found to be higher for TKF and interestingly the minimum concentration of the Phosphorus was found for the topsoil of PL. The phosphorus concentration varied as $\mathrm{HCl}>\mathrm{NaOH}>\mathrm{NaHCO}_{3}>\mathrm{H}_{2} \mathrm{O}$. The phosphorus fractions $\mathrm{HCl}$ associated was always higher and water-soluble phosphorus was lowest in the both soil horizons.

\section{Conclusions}

The work showed that the amount of phosphorus and associated soil macro-nutrients varied from thick forest to cultivated lands. In contrast to arable land use systems, the think forests showed a similar phosphorus status both for subsoil and topsoil. Overall, the variations of the plant essential nutrients were in the order of $\mathrm{Ca}>\mathrm{K}>\mathrm{Mg}$. It can be inferred that the conversion of thick forests to thin forests and/ or deforestation to increase the arable surface area may increase the phosphorus losses hence this should remain intact in order to keep the sustainable plant productivity.

\section{Acknowledgements}

The work was supported by Department of Environmental Sciences, COMSATS University Islamabad, Abbottabad Campus, Pakistan.

\section{Conflict of Interest}

The authors declare no conflict of interest.

\section{References}

1. GRIMM N.B., FAETH S.H., GOLUBIEWSKI N.E., REDMAN C.L., WU J., BAI X., BRIGGS J.M. Global change and the ecology of cities. Sci. 319 (5864), 756, 2008.
2. ROBINSON D.A., HOPMANS J.W., FILIPOVIC V., VAN DER PLOEG M., LEBRON I., JONES S.B., REINSCH S., JARVIS N., TULLER M. Global environmental changes impact soil hydraulic functions through biophysical feedbacks. Global Change Biol. 25 (6), 1895, 2019.

3. PARAMESH V., ARUNACHALAM V., NATH A.J. Enhancing ecosystem services and energy use efficiency under organic and conventional nutrient management system to a sustainable arecanut based cropping system. Energy. 187, 115902, 2019.

4. CETIN M. The effect of urban planning on urban formations determining bioclimatic comfort area's effect using satellitia imagines on air quality: a case study of Bursa city. Air Qual Atmos Hlth. 12 (10), 1237, 2019.

5. CETIN M., ZEREN I., SEVIK H., CAKIR C., AKPINAR H. A study on the determination of the natural park's sustainable tourism potential. Environ Monit Assess. 190 (3), 167, 2018.

6. CETIN M. Determining the bioclimatic comfort in Kastamonu City. Environ Monit Assess. 18 7(10), 640, 2015.

7. CETIN M., ADIGUZEL F., KAYA O. SAHAP A. Mapping of bioclimatic comfort for potential planning using GIS in Aydin. Environ Dev Sustain. 20 (1), 361, 2018.

8. GUILLAUME T., DAMRIS M., KUZYAKOV Y. Losses of soil carbon by converting tropical forest to plantations: erosion and decomposition estimated by $\delta 13 \mathrm{C}$. Global Change Biol. 21 (9), 3548, 2015.

9. GATTO M., WOLLNI M., QAIM M. Oil palm boom and land-use dynamics in Indonesia: the role of policies and socioeconomic factors. Land use policy. 46, 292, 2015.

10. MEHDI B., LEHNER. B., LUDWIG R. Modelling cropland use change derived from influencing factors selected and ranked by farmers in North temperate agricultural regions. Sci Total Environ. 631, 407, 2018.

11. DOMINATI E., PATTERSON M., MACKAY A. A framework for classifying and quantifying the natural capital and ecosystem services of soils. Ecol Econ. 69 (9), 1858, 2010.

12. KEESSTRA S., NUNES J., NOVARA A., FINGER D., AVELAR D., KALANTARI Z., CERDÀ A. The superior effect of nature-based solutions in land management for enhancing ecosystem services. Sci Total Environ. 610, 997, 2018.

13. VOGEL H.J., BARTKE S., DAEDLOW K., HELMING K., KÖGEL-KNABNER I., LANG B., WIESMEIER M. A systemic approach for modeling soil functions. Soil. 4 (1), 83, 2018.

14. CETIN M., ADIGUZEL F., GUNGOR S., KAYA E. SANCAR M.C. Evaluation of thermal climatic region areas in terms of building density in urban management and planning for Burdur, Turkey. Air Qual Atmos Hlth. 12 (9), 1103, 2019.

15. YÜCEDAĞ C., KAYA L.G., AŞIKKUTLU H.S., SAĞIR, E. Sustaining Urban Forestry Activities: The Case Study of Çivril District, Denizli-Turkey. Mehmet Akif Ersoy Üniversitesi Fen Bilimleri Enstitüsü Dergisi, 9(Ek (Suppl.) 1, 216, 2019.

16. JIMÉNEZ J.S.B., OCHOA I., DE LA CRUZ TORRES E., MURAOKA T. Effects of land use on phosphorus fractions and availability in an Andisol from the P'urhépecha Plateau, Michoacán. Revista Terra Latinoamericana. 37 (1), 35, 2019.

17. MARANGUIT D., GUILLAUME. T., KUZYAKOV Y. Land-use change affects phosphorus fractions in highly weathered tropical soils. Catena. 149, 385, 2017. 
18. AUGUSTO L., ACHAT D.L., JONARD M., VIDAL D., RINGEVAL B. Soil parent material - a major driver of plant nutrient limitations in terrestrial ecosystems. Global Change Biol. 23 (9), 3808, 2017.

19. AYALA-OROZCO B., GAVITO M.E., MORA F., SIDDIQUE I., BALVANERA P. JARAMILLO V.J., MARTÍNEZ-MEYE E. Resilience of Soil Properties to Land-Use Change in a Tropical Dry Forest Ecosystem. Land Degrad Dev. 2017.

20. TATARIW C., MACRAE J.D., FERNANDEZ I.J., GRUSELLE M.C., SALVINO C.J., SIMON K.S. Chronic Nitrogen Enrichment at the Watershed Scale Does Not Enhance Microbial Phosphorus Limitation. Ecosystems. 21 (1), 178, 2018

21. BOITT G., SIMPSON Z.P., TIAN J., BLACK A., WAKELIN S.A., CONDRON L.M. Plant biomass management impacts on short-term soil phosphorus dynamics in a temperate grassland. Biol Fert Soils. 1-13, 2018.

22. HOU E., TANG S., CHEN C., KUANG Y., LU X., HEENAN M., WEN D. Solubility of phosphorus in subtropical forest soils as influenced by low-molecular organic acids and key soil properties. Geoderma. 313, 172, 2018.

23. HOU E., CHEN C., KUANG Y., ZHANG Y., HEENAN M., WEN D. A structural equation model analysis of phosphorus transformations in global unfertilized and uncultivated soils. Global Biogeochem Cy. 30 (9), 1300, 2016.

24. WUENSCHER R., UNTERFRAUNER H., PETICZKA R., ZEHETNER F. A comparison of 14 soil phosphorus extraction methods applied to 50 agricultural soils from Central Europe. Plant Soil Environ. 61 (2), 86, 2015.

25. HOU E., CHEN C., WEN D., LIU X. Phosphatase activity in relation to key litter and soil properties in mature subtropical forests in China. Sci Total Environ. 515, 83, 2015.

26. LUN F., LIU J., CIAIS P., NESME T., CHANG J., WANG R., OBERSTEINER M. Global and regional phosphorus budgets in agricultural systems and their implications for phosphorus-use efficiency. Earth Syst Sci Data. 10 (1), 1, 2018.

27. REED S.C., YANG X., THORNTON P.E. Incorporating phosphorus cycling into global modeling efforts: a worthwhile, tractable endeavor. New Phytol. 208 (2), 324, 2015.

28. SIMONSSON M., ÖSTLUND A., RENFJÄLL L., SIGTRYGGSSON C., BÖRJESSON G., KÄTTERER T. Pools and solubility of soil phosphorus as affected by liming in long-term agricultural field experiments. Geoderma. 315, 208, 2018.

29. ALEXANDRATOS N., BRUINSMA J. World agriculture towards 2030/2050. The revision, 2012.

30. ROY E.D., RICHARDS P.D., MARTINELLI L.A., DELLA COLETTA L., LINS S.R.M., VAZQUEZ F.F., WILLIG E., SPERA S.A., VANWEY L.K., PORDER S. The phosphorus cost of agricultural intensification in the tropics. Nat. Plants. 2 (5), 16043, 2016.

31. ROY E.D., WILLIG E., RICHARDS P.D., MARTINELLI L.A., VAZQUEZ F.F., PEGORINI L., PORDER S. Soil phosphorus sorption capacity after three decades of intensive fertilization in Mato Grosso, Brazil. Agr Ecosyst Environ. 249, 206, 2017.

32. BENNETT E.M., CARPENTER S.R., CARACO N.F. Human Impact on Erodable Phosphorus and
Eutrophication: A Global Perspective: Increasing accumulation of phosphorus in soil threatens rivers, lakes, and coastal oceans with eutrophication. AIBS Bulletin. 51 (3), 227, 2001.

33. YANG W., CHENG H., HAO F., OUYANG W., LIU S., LIN C. The influence of land-use change on the forms of phosphorus in soil profiles from the Sanjiang Plain of China. Geoderma. 189, 207, 2012.

34. MOODIE C.D., SMITH H.W., MCCREERY R.A. Laboratory Manual for Soil Fertility. 71 (5), 400, 1959.

35. BLACK C.A. Methods of Soil Analysis Part 1 And 2. ASA, Inc. USA, 1965.

36. RICHARDS L. US Salinity Lab. Staff. Diagnosis and improvement of saline and alkali soil. USDA Handbook. 60, 1954.

37. THOMAS G.W. Soil $\mathrm{pH}$ and soil acidity. In 'Methods of soil analysis. Part 3. Chemical methods'. (Ed. DL Sparks). Soil Sci Soc Am J. Madison, WI. 475, 1996.

38. HEDLEY M.J., STEWART J.W.B., CHAUHAN B. Changes in inorganic and organic soil phosphorus fractions induced by cultivation practices and by laboratory incubations. Soil Sci Soc Am J. 46 (5), 970, 1982.

39. DOU Z., TOTH J.D., GALLIGAN D.T., RAMBERG C.F., FERGUSON J.D. Laboratory procedures for characterizing manure phosphorus. J Environ Qual. 29 (2), 508, 2000.

40. THOMAS G.W. Exchangeable cations. Methods of soil analysis. Part 2. Chemical and microbiological properties, (methodsofsoilan2). 1595, 1994.

41. IBSRAM. Soil, Water, and Nutrient Management Research, A New Agenda (CGIAR document MT/94/07). International Board for Soil Research and Management, Thailand, 1994.

42. S.A.S. Statistical Analysis System User's Guide, A.A. Ray, (Ed.), SAS Institute, Inc. Cary, NC, 1999.

43. LAGACHERIE P., ÁlVARO-FUENTES J., ANNABI M., BERNOUX M., BOUARFA S., DOUAOUI A., SABIR M. Managing Mediterranean soil resources under global change: expected trends and mitigation strategies. Reg Environ Change. 18 (3), 663, 2018.

44. SHARPLEY A.N. Global issues of phosphorus in terrestrial ecosystems. Phosphorus Biogeochemistry in Subtropical Ecosystems, 15, 1999.

45. HORST W.J., KAMH M., JIBRIN J.M., CHUDE V.O. Agronomic measures for increasing $\mathrm{P}$ availability to crops. Plant Soil. 237 (2), 211, 2001.

46. SOLOMON D., LEHMAN N. Loss of phosphorus from soil in semi-arid northern Tanzania as a result of cropping: evidence from sequential extraction and 31P-NMR spectroscopy. EUR J SOIL SCI. 51 (4), 699, 2000.

47. WANG G.P., ZHAI Z.L, LIU J.S., WANG J.D. Forms and profile distribution of soil phosphorus in four wetlands across gradients of sand desertification in Northeast China. Geoderma. 145 (1-2), 50, 2008.

48. REDDY K.R., O'CONNOR G.A., SCHELSKE C.L. Symposium overview and synthesis. Phosphorus Biogeochemistry in Subtropical Ecosystems. Lewis Publishers, Boca Raton, FL. 3, 1999.

49. SHERLOCK R.R. Seasonal changes in soil phosphorus and associated microbial properties under adjacent grassland and forest in New Zealand. Forest Ecol Manag. 177 (1-3), 539, 2003.

50. DIJKSTRA F.A. Calcium mineralization in the forest floor and surface soil beneath different tree species in the northeastern US. Forest Ecol Manag. 175 (1-3), 185, 2003. 